ENTREPRENEURSHIP AND SUSTAINABILITY ISSUES

ISSN 2345-0282 (online) http://jssidoi.org/jesi/

2020 Volume 8 Number 2 (December)

http://doi.org/10.9770/jesi.2020.8.2(43)

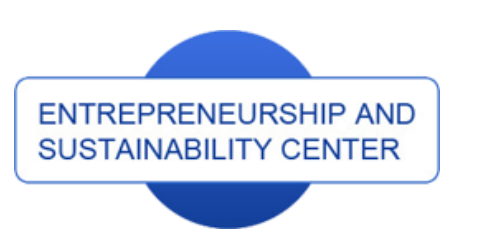

Publisher

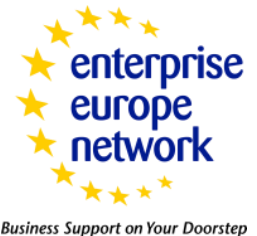

CASPA

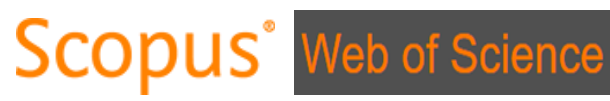

http://jssidoi.org/esc/home

Business Support on Your Doorstep

1 Clarivate

Analytics

\title{
EXPLICATING ENERGY SAVING INTENTION FROM THE PROSPECT OF SMALL MEDIUM ENTERPRISES
}

\author{
Phuong V. Nguyen ${ }^{1 *}$, Khoa T. Tran ${ }^{2}$ \\ 1,2 International University, Vietnam National University, \\ Quarter 6, Linh Trung Ward, Thu Duc District, Ho Chi Minh City, Vietnam \\ E-mails: ${ }^{1 *} \underline{\text { nvphuong@hcmiu.edu.vn }}$ (Corresponding author); ${ }^{2}$ ttkhoa@hcmiu.edu.vn
}

Received 15 March 2020; accepted 16 September 2020; published 30 December 2020

\begin{abstract}
Saving energy at workplaces has become a major concern in enterprises because it offers a valuable opportunity to reduce energy consumption and lessen carbon dioxide emissions, which affect the global climate change and human health. This study integrated and extended both theories of planned behavior and social information processing to identify key determinants that influence on middle managers' energy saving intention at workplaces. By using the Partial Least Squares-Structural Equation Modeling (PLS-SEM) method to scrutinize a data survey of 336 middle managers in small medium enterprises located in Ho Chi Minh City (HCMC), Vietnam. The findings confirmed the central role of top management support in stimulating middle managers to engage in energy saving responsibility. Moreover, under social pressure, managers are willing to change and enhance subordinates to reduce energy consumption. Meanwhile, perceived environmental responsibility has a significant indirect impact on energy saving intention through proactive behavior, but not a direct impact. Based on the results, this study enriched the literature on energy saving behavior and drew managerial implications for enterprises
\end{abstract}

Keywords: energy saving intention; social pressure; top management support; proactive behaviour; openness toward change; perceived environmental responsibility; SMEs

Reference to this paper should be made as follows: Nguyen, V.P., Tran, T.K. (2020). Explicating Energy Saving Intention from the Prospect of Small Medium Enterprises. Entrepreneurship and Sustainability Issues, 8(2), 716-734. http://doi.org/10.9770/jesi.2020.8.2(43)

JEL Classifications: M12, M14, Q01

\section{Introduction}

The worldwide energy consumption has been rapidly increasing over the last decade (Zhang, Wei, and Zhou, 2018). The International Energy Agency reports that the demand for energy is forecasted to rise by nearly 35\% from present until 2035 (Tan, Ooi, \& Goh, 2017). Consequently, energy prices have gone up, meanwhile the world energy supplies have been unstable (Bissing-Olson et al., 2013; Tang, Warkentin, and Wu, 2019). 
Make your research more visible, join the Twitter account of ENTREPRENEURSHIP AND SUSTAINABILITY ISSUES: @Entrepr69728810

Moreover, the fast rising energy consumption has caused numerous environmental problems as well as enhanced the global climate change, which has obstructed sustainable development. As one of the most dynamic emerging countries in East Asia region, Vietnam has increased energy demand by 10\% per year. In reference (Le, 2019), the current energy consumption is extremely inefficient. Electricity consumption has surged by nearly $13 \%$ per annum. The demand for generation capacity increased from $8.7 \mathrm{GW}$ in 1990 to $27 \mathrm{GW}$ in 2000 and achieved greater than $48 \mathrm{GW}$ in 2018. Primary energy consumption increased from 31 million tons of oil equivalent in 2005 to around 75 million tons in 2017.

As the process of fundamental industrialization is attained, the structure transformation process transits gradually to high-efficiency industries with less energy consumption, and economic growth of countries impels decrease in the energy intensity of Gross Domestic Product (GDP) (Burke \& Csereklyei, 2016). Accessing to World Bank database (World Bank, 2019), the quantity of primary energy in terms of (MJ) per GDP (2011 PPP) presented in Figure 1. In 2015, Vietnam's energy intensity was 5.9, which is higher than in India (4.7) and other ASEAN (such as Malaysia (4.7), Singapore (2.4), Philippines (3.1), Indonesia (3.5), Thailand (5.4), Myanmar (3.1), Lao (5.2)). It implies that Vietnam has been using highly energy for a unit of economic output. The main concern is that the increase in energy consumption induces higher carbon dioxide (CO2) emissions and other greenhouse gasses, which affect the global climate change and human health (Tang et al., 2019; Wang, Zhang, and Li, 2014).

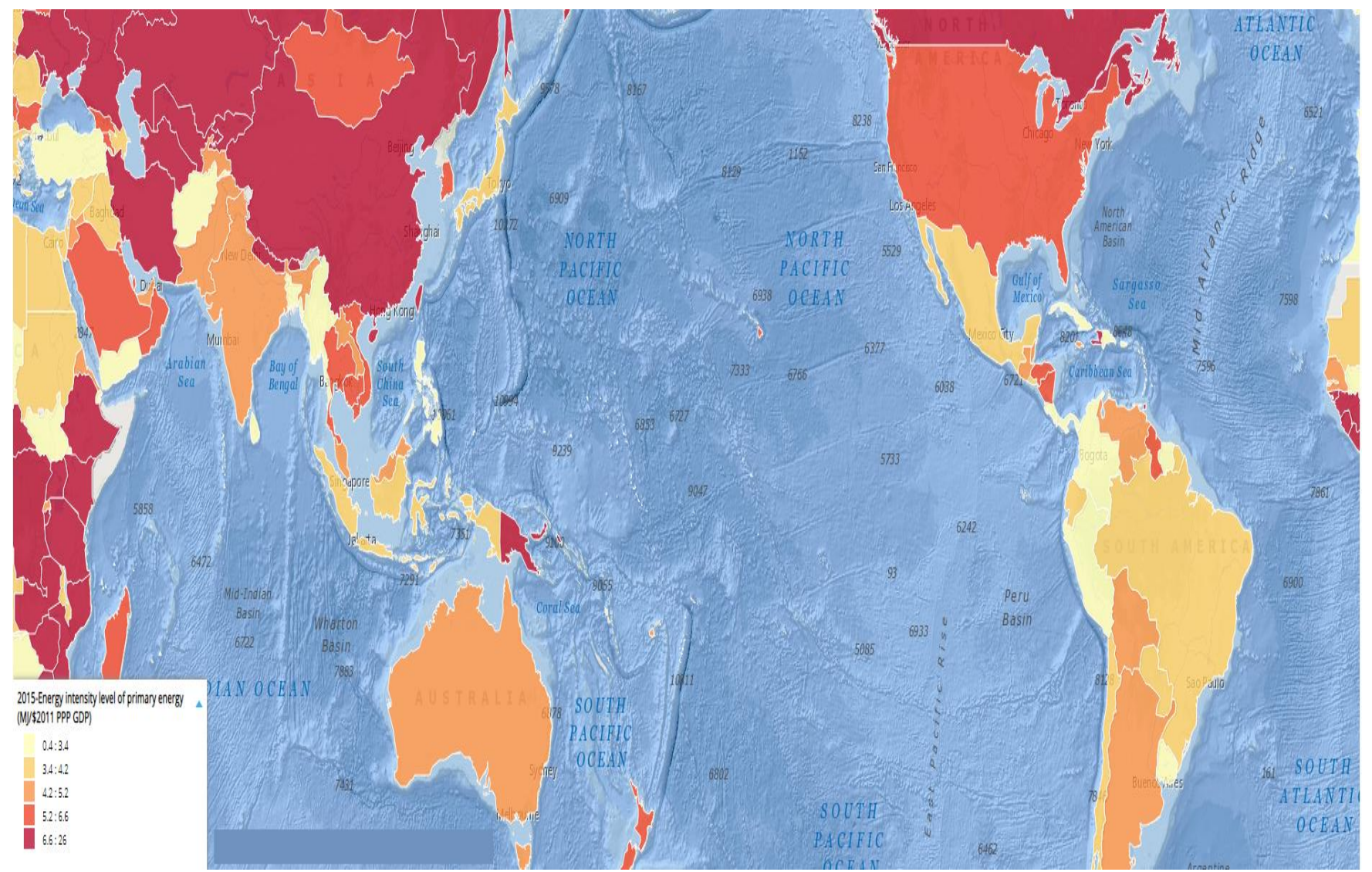

Figure 1. Primary energy (Source: World Bank) 


\section{ENTREPRENEURSHIP AND SUSTAINABILITY ISSUES}

ISSN 2345-0282 (online) http://jssidoi.org/jesi/

2020 Volume 8 Number 2 (December)

http://doi.org/10.9770/jesi.2020.8.2(43)

Make your research more visible, join the Twitter account of ENTREPRENEURSHIP AND SUSTAINABILITY ISSUES: @Entrepr69728810

In the other side, pursuing the environmental protection programs is adversely diminishing the profitability of many companies (Scherbaum, Popovich, \& Finlinson, 2008), thus researchers and practitioners are seeking for solutions lessen energy consumption at workplaces (Gao et al., 2017; Leygue, Ferguson, and Spence, 2017; Tang et al., 2019; Zhang, Wang, and Zhou, 2014). The academic literature proposes that to reduce energy consumption at workplaces, companies seek for transforming organizational structure and changing operations management such as investing in energy-efficient equipment (Scherbaum et al., 2008). However, purchasing energy-efficient products and enhancing efficient energy use are not enough to reduce energy consumption in long periods of time due to the so-called "rebound effect" (Chitnis et al., 2013; Gao et al., 2017). When using energy-efficient machinery, people seem to consume more electricity. For instance, people may turn on an air condition for longer hours or set a lower temperature since they believe in new technology for greater energy savings.

Because of this puzzlement, energy saving behavior has attracted into an emerging research field. According to Scherbaum et al. (2008), enterprises and their workers are one of the numerous users of the global energy. Various enterprises have recognized the significant role of managers and employees in saving energy at workplaces and searched for guidance procedures to ensure employees stay proactively engaged with energy saving (Zhang et al., 2014). However, many present studies on energy saving behavior at the individual level primarily concentrated on energy saving of households (Liu et al., 2020; Wang, Lin, \& Li, 2018; Yue, Long, \& Chen, 2013). Whereas other prior studies largely explored customers' attitudes toward using energy efficiency (Gadenne et al., 2011; Hua and Wang, 2019). In addition, the present literature on energy consumption at workplaces substantially focuses on employee energy saving behavior (Tang et al., 2019; Zhang et al., 2014). A research gap still exists in examining the role of middle managers in energy consumption behavior in Small Medium Enterprises (SMEs), although the many attempts have been conducted to bridge it. Enterprises expect employees, particularly middle managers, devote more effort as well as engage change-oriented behaviors (Griffin, Parker, \& Mason, 2010). By pursuing innovative ideas and initiating and implementing changes, managers have to seek for appropriate solutions to reduce energy consumption and adapt to new environmental laws, as well as overcome particular challenges to keep their job. Thus, we investigate which determinants lead to middle managers' proactive behavior and energy saving intention at workplaces.

Extant research on the energy saving at workplaces has largely concentrated on employees' attitude and exercised the conceptual framework based on the theory of planned behavior (TPB) (Ajzen, 1991) to clarify energy saving behavior of employees (Gao et al., 2017). Other studies extended rational choice theory to illustrate that energy saving behavior of employees is based on the cost-benefit analysis (Leygue et al., 2017; Zhang et al., 2014). In addition, in the recent study, Bao, Wang, \& Sun (2019) employed social information processing theory to evaluate the mediating role of middle managers in adapting environmental regulations and implementing proactive behavior at workplaces. Meanwhile, another study of Tang et al. (2019) employed stimulus-organism response theory to develop the research framework. The scholars attempt to identify the factors motivating employees' energy-saving intention. In this study, we integrated and expanded both theories of TPB and social information processing to develop the conceptual framework to answer the key research question above.

This paper makes several essential contributions to our knowledge of this crucial phenomenon. First, it examines the determinants that lead middle managers' energy saving intention in SMEs, hence this research field has been extended in the new context. Second, while most previous research mainly employed one of common theories (e.g. TPB, rational choice theory, stimulus-organism response, and social information processing), this paper integrated and extended both theories to clarify the central role of top management support in connecting explanatory factors (e.g. social pressure, openness toward change, proactive behavior) that influence on middle 


\section{ENTREPRENEURSHIP AND SUSTAINABILITY ISSUES}

ISSN 2345-0282 (online) http://jssidoi.org/jesi/

2020 Volume 8 Number 2 (December)

http://doi.org/10.9770/jesi.2020.8.2(43)

Make your research more visible, join the Twitter account of ENTREPRENEURSHIP AND SUSTAINABILITY ISSUES: @Entrepr69728810

managers' energy saving intention. Finally, this research is expected to provide fruitful insights to assist policymakers to stimulate middle managers to engage in energy saving responsibility.

The remaining of this paper is structured as follows. The following section reviews the prior literature on energy saving intention and relevant theories to build the research model. Then, Section 3 describes the research methodology and data collection. Data analysis and empirical results are presented in Section 4. In Section 5, we discuss the research findings and highlight theoretical and managerial contributions. The final section presents conclusions with the limitations.

\section{Literature review}

\subsection{Energy saving intention}

Many technical solutions have been created to reduce energy consumption that behavioral changes have substantially favorable influences on decreasing carbon emissions and fighting global warming (Tang et al., 2019; Zhang et al., 2018). Therefore, the behavioral trend has appealed immense attentions from scholars in the current period. Previous studies of energy-saving behavior has concentrated on individual settings (Al-Shemmeri and Naylor, 2017; Gao et al., 2017), instead of companies' energy-saving behavior. Several studies have also attempted to investigate how socio-demographics and psychological factors relate to energy-saving goals. For instance, in reference (Ding et al., 2017), it illustrated that urban residents in China are more likely to engage in energy-saving activities than rural residents. Likewise, another study in China showed that females paid more attention to energy saving than male due to the Chinese family culture, wives are often responsible for controlling household expenditure (Yang, Zhang, \& Zhao, 2016). In addition, other studies investigated the linkage between energy saving behavior and psychological factors by examining specific variables of psychological components (e.g. attitude, values, beliefs, and social norms) (Frederiks, Stenner, \& Hobman, 2015; S. Wang et al., 2018).

In recent studies, scholars have also started to investigate the determinants of employees' energy-saving behavior at workplaces (Gao et al., 2017; Tang et al., 2019). They have explored the possible influences of employees' socio-demographics and psychological components on energy-saving behavior. For instance, by conducting a questionnaire survey from United Kingdom college employees, the scholars found that socio-demographic features, such as commute category, social altruism, homeowner status, and use of home green appliances, affected employees' commitment to actual energy savings at workplaces (Al-Shemmeri \& Naylor, 2017). Another study on Chinese office workers proved that worker's attitude, perceived behavior control, descriptive and personal moral norm have a significantly positive impact on energy-saving behavior (Gao et al., 2017). Similarly, by analyzing data from Chinese office employees, Tang et al. (2019) found that energy saving intention had a positively significant relationship with both employee's social pressure and perceived energy saving responsibility.

\subsection{Top management support}

Top managers are responsible for making the organizational decisions, are critical for organizational. Several prior studies have examined the effect of top managers on companies' energy-saving behavior. For instance, Blass et al. (2014) analyze data collection from top operations managers of small medium manufacturing firms in the United States. They find that the top operations managers' engagement significantly raises the adoption energyefficiency initiatives. Whereas, Zhang, Wang, and Lai (2015), conducting a data survey of senior managers from industrial firms in China, show that senior managers' environmental concern mediates between firms' operational practice and energy-saving strategy. 


\section{ENTREPRENEURSHIP AND SUSTAINABILITY ISSUES}

ISSN 2345-0282 (online) http://jssidoi.org/jesi/

2020 Volume 8 Number 2 (December)

http://doi.org/10.9770/jesi.2020.8.2(43)

Make your research more visible, join the Twitter account of ENTREPRENEURSHIP AND SUSTAINABILITY ISSUES: @Entrepr69728810

According to Schumpeterian viewpoint of competition, companies are able to gain competitive advantages over time by executing actions (Jacobson, 1992). Environmental management activities are a kind of actions that companies can execute to achieve a sustainable competitive advantage (Dai, Montabon, \& Cantor, 2014). Therefore, under the competitive pressure, company leaders should support for the environmental initiatives to gain a competitive advantage. Moreover, Zhang et al. (2018) show that top management support has a significant impact on energy-saving behavior. In addition, executing environmental initiatives requires many resources such human, capital, technologies. With the top management support, these resources are given to a remarkable extension. So, the first hypothesis was proposed:

H1. Top management support is a positive influence on energy saving intention.

\subsection{Social pressure}

Social pressure, one type of the subjective norms, confers to the pressure level of an individual perceived from essential others to carry or not carry the behavior (Frederiks et al., 2015; Tang et al., 2019; Wang et al., 2018). It means that if an individual perceives the substantial other people such as friends, colleagues, leaders, or relatives, expect him or her to pledge a specific behavior, he/she is more likely to employ the behavior. When managers have to perform four primary functions such as planning, organizing, leading and controlling at workplaces, they may feel more pressure not to do the right things under social pressure on environmental management activities. Therefore, they may create some approaches to motivate employees to reduce energy use in the workplace. They also face social pressure to commit to solve societal and environmental problems. Specifically, top-level managers want to follow opportunities and strategies that deal with environmental and social factors to gain sustainable development (Jahanshahi \& Brem, 2017). Previous empirical results showed that social pressure is a key determinant of energy saving intention (Wang et al., 2018; Yue et al., 2013). In the recent empirical study on Chinese office workers, Tang et al. (2019) find that social pressure is positively associated with energy saving intention in the workplace. Another recent study on 207 families in northwest China also finds out that subject norm has a significant influence on energy saving intention at home. Hence, the following hypotheses were proposed:

H2. Social pressure has a significant effect on energy saving intention.

H3. Social pressure is a significant effect on top management support.

\subsection{Proactive behavior and openness toward change}

Proactive behavior is broadly defined as "taking initiative in improving current circumstances or creating new ones; it involves challenging the status quo rather than passively adapting to current conditions" (Crant, 2000). General components of proactive behavior involve actively searching out information, determining room for improvement, establishing constructive change-oriented recommendations and figuring out appropriate ways to improve a circumstance (Bao et al., 2019). This paper explored perceptions of environmental regulation. Middle managers need to change their attitudes and behaviors to comply with the environmental laws and regulations. Based on social information processing theory, middle managers are supposed to be more open to change, particularly since environmental laws stimulates middle managers to acknowledge the need for change (Bao et al., 2019).

Previous studies have shown that proactive behavior has a strong linkage with individual and organizational outcomes such as entrepreneurial behaviors (Becherer \& Maurer, 1999), sales performance (Crant, 1995), individual innovation (Seibert, Kraimer, \& Crant, 2001), and small-firm innovation (Kickul \& Gundry, 2002). Moreover, some scholars also investigate the relationships among the individual and work environment determinants with proactive behavior at workplace. For instance, using data collection from United Kingdom wire makers, Parker, Williams, \& Turner (2006) identify direct antecedents such as job autonomy, flexible role 


\section{ENTREPRENEURSHIP AND SUSTAINABILITY ISSUES}

ISSN 2345-0282 (online) http://jssidoi.org/jesi/

2020 Volume 8 Number 2 (December)

http://doi.org/10.9770/jesi.2020.8.2(43)

Make your research more visible, join the Twitter account of ENTREPRENEURSHIP AND SUSTAINABILITY ISSUES: @Entrepr69728810

orientation and role breadth self-efficacy, which have a positively significant impact on proactive behavior. By analyzing a data collection of 491 supervisors from 32 Australian state organizations, Griffin, Neal, \& Parker (2007) show that open to change has a positive relationship with proactivity in all terms of organization member, team member, and individual task. Moreover, to explore other potential antecedents, in a recent study, Bao et al. (2019) illustrate that openness toward change has a positive impact on proactive behavior.

Prior studies on proactivity have proposed that the settlement to pledge in proactive behaviors needs information sharing. For instance, managers should motivate employees to express proactive behavior at workplace. In other words, organizations that concentrate on increasing employee proactivity need to invest in many kinds of supportive mechanisms in terms of competence development and information sharing. The more transparent information, the better employees can focus on improving their performance instead of being disappointed by feeling of unrecognized their contributions (Maden, 2015). Moreover, quality of information given to employees enables them to understand potential problems and recognize opportunities. Therefore, managers need to provide reliable information to help employees to forecast and understand what affect their working climate in advance (Escrig-Tena, Segarra-Ciprés, García-Juan, \& Beltrán-Martín, 2018; Grant \& Ashford, 2008). Based on the prior results, the following hypotheses were proposed:

H4: Top management support has a positive relationship with openness toward change.

H5: Openness toward change has a positive relationship with proactive behavior.

H6: Top management support has a positive relationship with proactive behavior.

\subsection{Perceived environmental responsibility}

Perceived environmental responsibility reflects individual's behavior to environment protection. For instance, Lee (2009) investigates gender difference in perceived environment responsibility through data survey of 48 high schools in Hong Kong. The findings show that both female and male concern perceived environmental responsibility when buying green products. With this perception, consumers would consider high-carbon consumption as irresponsible and selfish actions. In other words, they would have a sense of responsibility and engage in pro-environmental behaviors (Rice, 2006; Wang, Wei, and Zhang, 2019). In addition, they could also search for improving their standing by implementing environmentally friendly practices (Lee, 2009). In this study, we explore how managers' responses to environmental responsibility at workplace. We suppose that managers play an essential role in leading to environmental awareness. Moreover, according to the face negotiation theory, as perceiving an environmental responsibility, managers who are concerned with preservation of their face consciousness would intend to pursue energy saving measures since they can attain face and status power by participating into environmental protection to create a positive image at work (Wang et al., 2019).

Furthermore, according to the theory of planned behavior (TPB), behavioral intention is influenced by three factors (subjective norms, perceived behavioral control, and attitude towards behavior). Other previous studies have expanded the TPB by appending descriptive norms to reflect the new social influence, and proposed enlarged explanatory power of behavioral intention (Cristea, Paran, and Delhomme, 2013; Forward, 2009; Li et al., 2019). Specifically, descriptive norms have played an important role in considering solar with a low perceived behavioral control (Rai \& Beck, 2015). In general, the TPB is proved as an appropriate framework to estimate energy-saving behaviors (Kaiser \& Gutscher, 2003; Li et al., 2019; Rai \& Beck, 2015; Scherbaum et al., 2008). This paper extended the TPB by considering perceived environmental responsibility as predicting energy-saving intention at workplaces. Moreover, it is worth noting that perceived behavioral control is an essential determinant of behavioral intention in several studies (Botetzagias, Dima, \& Malesios, 2015; Hua \& Wang, 2019; Lizin, Van Dael, \& Van Passel, 2017; Ru, Wang, \& Yan, 2018). Some external situations, including time, cost, resources, managerial skills and knowledge, are possibly free from individual control, and hence influence personal intention 
Make your research more visible, join the Twitter account of ENTREPRENEURSHIP AND SUSTAINABILITY ISSUES: @Entrepr69728810

to join in a particular practice (Ru et al., 2018). In this paper, we suppose that proactive behavior is considered as one specific type of perceived behavioral control. If managers feel responsibilities for their tasks and have management skills and relevant knowledge to save energy at workplace, they attempt to seek for appropriate ways to conserve energy. It implies that perceived environmental responsibility could influence both energy saving intention and proactive behavior. Thus, the following hypotheses were proposed:

H7: Perceived environmental responsibility is positively associated with energy saving intention

H8: Perceived environmental responsibility is positively associated with proactive behavior

H9: Proactive behavior is positively associated with on energy saving intention

Albeit the previous studies shed light on the energy saving behavior, the research endeavor in this field is still at an initial stage. Most of the present literature has concentrated on either household energy savings or office workers. Middle managers in SMEs comprise a crucial goal group for determining energy saving, but little research attempt has been expanded to investigate what motivates middle managers to save energy at workplaces. To fulfill this gap in the literature, we integrate both theories (TPB and social information processing) to build a research model for examining the role of social pressure, top management support, internal psychological behaviors (proactive behavior) and perceived environmental responsibility in energy saving intention in SMEs. Figure 2 presents the integrated research model.

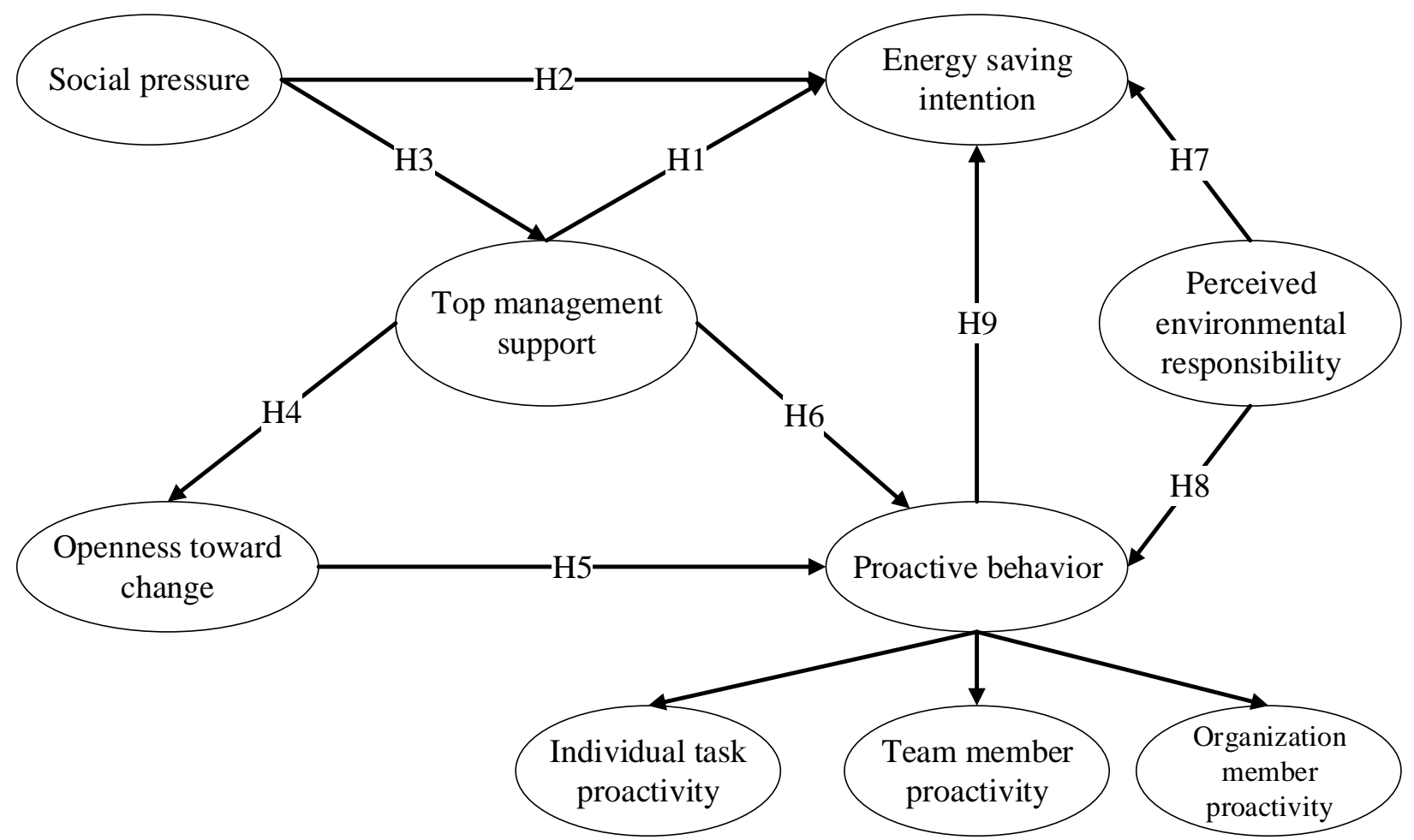

Figure 2. The research model 


\section{ENTREPRENEURSHIP AND SUSTAINABILITY ISSUES}

ISSN 2345-0282 (online) http://jssidoi.org/jesi/

2020 Volume 8 Number 2 (December)

http://doi.org/10.9770/jesi.2020.8.2(43)

Make your research more visible, join the Twitter account of ENTREPRENEURSHIP AND SUSTAINABILITY ISSUES: @Entrepr69728810

\section{Research design}

\subsection{Measurements}

All measured items were adapted from previous literature with some adjustments to conform the research context in Vietnam. The questionnaire was initially developed in English version. We followed three procedures to complete the questionnaire. First, the questionnaire was translated into Vietnamese by researchers whose mother language is Vietnamese. Second, we conducted a focus group with two professors and three managers to help us to check the Vietnamese questions. Hereafter, they suggested some adjustments to ensure respondent understand the questions. Third, a pilot test with 20 managers was implemented to satisfy no errors and appropriate contends. We designed a five-point Likert scale ranging from "strongly disagree" to "strongly agree" for all items.

The latent variable of social pressure is adapted from (Tang et al., 2019; Wang et al., 2014) with four items. Two sample items include "my colleagues expect me to save energy" and "I feel pressured due to the energy-saving activities of my colleague". The construct of energy-saving intention is developed from (Gao et al., 2017; Park and Kwon, 2017; Tang et al., 2019) with four items. A sample item includes "I am willing to save energy for my company". Perceived environmental responsibility including five items is adapted from (Lee, 2009; L. Wang et al., 2019). A sample modified item consists of "I strongly agree that more environmental protection works are needed at workplaces". Top management support consisting of four items is adapted from (Wang et al., 2018). The latent variable of openness toward change is developed by (Bao et al., 2019; Miller et al., 1994). Proactive behavior is a second order factor including three sub-factors such as organization member, team member, and individual task (Griffin et al., 2007). This factor is adapted from (Bao et al., 2019; Griffin et al., 2007). The measured items with denotes and their sources are presented in Appendix A, Table A1.

\subsection{Data collection}

A questionnaire survey approach was used to collect data. All respondents are middle managers from SMEs. It took five months to complete the data collection from June to November 2019. After modifying the questionnaire for appropriate research context in Vietnam, the questionnaire was deliverd to 400 middle managers of SMEs. It worth noting that the Center for Customer Service of Vietnam Electricity in HCMC assisted to select potential respondents. Particularly, it first introduced the authors to contact with 40 middle managers to conduct the survey. And then, like a snowballing approach, these managers continued to introduce us to contact other managers. In addition, the authors also received valuable supports for conducting the survey from MBA students, who are placed in the position of managers in enterprises. Finally, after checking all returned questionnaires, responses with missing information were removed. As a result, 336 responses were used for data analysis.

\section{Results}

\subsection{Demographic characteristics}

Demographic characteristics consisted of gender, age, education, managing field, and exprerience in the management position. Most respondents are male and account for $80.95 \%$ of the total respondents. $47.02 \%$ of the respondents were between 41 and 49. For the educational level, most of the respondents held a bachelor's degree or higher. $44.05 \%$ of the respondents had management experience in production factory. Finally, $50.60 \%$ of the respondents had more than 15 years in the management position. Table 1 presented the demographic profile of the respondents. 
ENTREPRENEURSHIP AND SUSTAINABILITY ISSUES

ISSN 2345-0282 (online) http://jssidoi.org/jesi/

2020 Volume 8 Number 2 (December)

http://doi.org/10.9770/jesi.2020.8.2(43)

Make your research more visible, join the Twitter account of ENTREPRENEURSHIP AND SUSTAINABILITY ISSUES: @Entrepr69728810

Table 1. The respondents' demographics

\begin{tabular}{clrr}
\hline Characteristics & \multicolumn{1}{c}{ Items } & Count (N=336) & Percent \\
\hline \multirow{2}{*}{ Gender } & Male & 272 & 80.95 \\
& Female & 64 & 19.05 \\
\hline \multirow{2}{*}{ Age } & $25-30$ & 58 & 17.26 \\
& $31-40$ & 71 & 21.13 \\
& $41-49$ & 158 & 47.02 \\
& $>50$ & 49 & 14.58 \\
\hline \multirow{2}{*}{ Education } & Bachelor Degree & 260 & 77.38 \\
& Master Degree & 72 & 21.43 \\
& PhD. Degree & 4 & 1.19 \\
\hline \multirow{2}{*}{ Manager in } & Finance/Accounting & 64 & 19.05 \\
& Production factory & 148 & 44.05 \\
& Marketing & 29 & 8.63 \\
& Plan and development & 47 & 13.99 \\
& Material supply & & 8.33 \\
& Customer services & 28 & 4.76 \\
& Others & 16 & 1.19 \\
\hline
\end{tabular}

\subsection{Analysis and results}

PLS-SEM approach was employed to test the hypotheses with support SmartPLS 3.0. It is a suitable approach for examining a complicated model with many contemporary relationships (Tran \& Nguyen, 2020). Before analyzing the data and testing the research hypotheses, we need to observe the descriptive statistics for our variables (Nyangarika, Mikhaylov, \& Richter, 2019). Table 2 reports descriptive statistics of all measured items. The rule of thumb demonstrates that each outer loading should be larger or equal to the threshold of 0.7 (Hair, Sarstedt, Hopkins, \& Kuppelwieser, 2014). To satisfy the threshold, the following items (PB9, PER5, OTC4 and OTC5) were eliminated due to low loadings. Table 2 reports the remaining outer loadings as being larger than 0.7 , which satisfy the reliability of the scale. Cronbach's alpha and composite reliability (CR) values are greater 0.8 and in the good range (Hair et al., 2014). Table 2 also shows that average variance extracted (AVE) values are greater than 0.5 , which meet the requirement for assessing convergent validity. 


\section{ENTREPRENEURSHIP AND SUSTAINABILITY ISSUES}

ISSN 2345-0282 (online) http://jssidoi.org/jesi/

2020 Volume 8 Number 2 (December)

http://doi.org/10.9770/jesi.2020.8.2(43)

Make your research more visible, join the Twitter account of ENTREPRENEURSHIP AND SUSTAINABILITY ISSUES: @Entrepr69728810

Table 2. Reliability and convergent validity

\begin{tabular}{|c|c|c|c|c|c|c|c|}
\hline Variables & Mean & $S D$ & $\begin{array}{c}\text { Factor } \\
\text { Loading }\end{array}$ & Alpha & Rho_A & $C R$ & $A V E$ \\
\hline \multicolumn{4}{|l|}{ Thresholds } & $\geq 0.6$ & $\geq 0.7$ & $\geq 0.7$ & $\geq 0.5$ \\
\hline \multicolumn{4}{|c|}{ Environmental saving intention (ESI) } & 0.894 & 0.900 & 0.927 & 0.761 \\
\hline ESI1 & 4.050 & 0.839 & 0.890 & & & & \\
\hline ESI2 & 4.155 & 0.741 & 0.923 & & & & \\
\hline ESI3 & 4.122 & 0.699 & 0.896 & & & & \\
\hline ESI4 & 4.161 & 0.723 & 0.773 & & & & \\
\hline \multicolumn{4}{|c|}{ Proactive behavior $(\mathrm{PB})$} & 0.909 & 0.910 & 0.926 & 0.611 \\
\hline \multicolumn{8}{|c|}{ Individual task proactivity } \\
\hline PB1 & 3.818 & 0.791 & 0.917 & & & & \\
\hline PB2 & 3.729 & 0.976 & 0.911 & & & & \\
\hline PB3 & 3.642 & 0.743 & 0.875 & & & & \\
\hline \multicolumn{8}{|c|}{ Team member proactivity } \\
\hline PB4 & 3.794 & 0.770 & 0.772 & & & & \\
\hline PB5 & 3.824 & 0.868 & 0.864 & & & & \\
\hline PB6 & 3.627 & 0.871 & 0863 & & & & \\
\hline \multicolumn{8}{|c|}{ Organization member proactivity } \\
\hline PB7 & 3.607 & 0.911 & 0.935 & & & & \\
\hline PB8 & 3.738 & 0.868 & 0.926 & & & & \\
\hline \multicolumn{4}{|c|}{ Openness toward change (OTC) } & 0.873 & 0.873 & 0.922 & 0.798 \\
\hline OTC1 & 4.023 & 0.936 & 0.906 & & & & \\
\hline OTC2 & 3.946 & 0.922 & 0.914 & & & & \\
\hline OTC3 & 3.720 & 0.917 & 0.858 & & & & \\
\hline \multicolumn{4}{|c|}{ Perceived environmental responsibility (PER) } & 0.888 & 0.892 & 0.922 & 0.747 \\
\hline PER1 & 3.616 & 0.932 & 0.853 & & & & \\
\hline PER2 & 3.705 & 0.904 & 0.870 & & & & \\
\hline PER3 & 3.782 & 0.963 & 0.858 & & & & \\
\hline PER4 & 3.821 & 0.812 & 0.876 & & & & \\
\hline \multicolumn{4}{|l|}{ Social pressure $(S P)$} & 0.893 & 0.897 & 0.926 & 0.757 \\
\hline SP1 & 4.440 & 0.692 & 0.854 & & & & \\
\hline SP2 & 4.404 & 0.680 & 0.887 & & & & \\
\hline SP3 & 4.458 & 0.676 & 0.846 & & & & \\
\hline SP4 & 4.333 & 0.730 & 0.892 & & & & \\
\hline
\end{tabular}


ENTREPRENEURSHIP AND SUSTAINABILITY ISSUES

ISSN 2345-0282 (online) http://jssidoi.org/jesi/

2020 Volume 8 Number 2 (December)

http://doi.org/10.9770/jesi.2020.8.2(43)

Make your research more visible, join the Twitter account of ENTREPRENEURSHIP AND SUSTAINABILITY ISSUES: @Entrepr69728810

\begin{tabular}{|c|c|c|c|c|c|c|c|}
\hline \multicolumn{4}{|c|}{ Top management support (TMS) } & \multirow[t]{2}{*}{0.904} & \multirow[t]{2}{*}{0.906} & \multirow[t]{2}{*}{0.933} & \multirow[t]{2}{*}{0.778} \\
\hline TMS1 & 3.919 & 0.918 & 0.889 & & & & \\
\hline TMS2 & 3.869 & 0.908 & 0.923 & & & & \\
\hline TMS3 & 3.994 & 0.933 & 0.875 & & & & \\
\hline TMS4 & 4.110 & 0.875 & 0.839 & & & & \\
\hline
\end{tabular}

Discriminant validity is confirmed when the square root of the AVE values should exceed the correlation between two particular constructs (Fornell \& Larcker, 1981). The findings on Table 3 satisfy this recommendation. In addition, Table 4 presents Heterotrait-Monotrait ratios, which are below 0.85 (Clark \& Watson, 1995). Hence, the two different assessments affirm the scale of the model to assure the discriminant validity (Tran \& Nguyen, 2020).

Table 3. Discriminant validity (Formell and Lacker)

\begin{tabular}{lcccccc}
\hline & \multicolumn{7}{c}{ Formell and Lacker's Criterion } \\
\cline { 2 - 7 } & ESI & OTC & PB & PER & SP & TMS \\
\hline Environmental saving intention (ESI) & $\mathbf{0 . 8 7 2}$ & & & & & \\
Openness toward change (OTC) & 0.354 & $\mathbf{0 . 8 9 3}$ & & & & \\
Proactive behavior (PB) & 0.397 & 0.379 & $\mathbf{0 . 7 8 2}$ & & & \\
Perceived environmental responsibility (PER) & 0.299 & 0.227 & 0.615 & $\mathbf{0 . 8 6 4}$ & & \\
Social pressure (SP) & 0.600 & 0.456 & 0.378 & 0.296 & $\mathbf{0 . 8 7 0}$ & \\
Top management support (TMS) & 0.456 & 0.613 & 0.396 & 0.212 & 0.480 & $\mathbf{0 . 8 8 2}$ \\
\hline
\end{tabular}

Notes: the square root of AVE on the diagonal.

Table 4. Discriminant validity (Heterotrait-Monotrait ratios of correlations).

\begin{tabular}{lcccccc}
\hline & ESI & OTC & PB & PER & SP & TMS \\
\hline Environmental saving intention (ESI) & \multicolumn{5}{c}{ Criteria $\leq 0.85$} \\
\cline { 2 - 7 } Openness toward change (OTC) & 0.404 & & & & \\
Proactive behavior (PB) & 0.443 & 0.425 & & & \\
Perceived environmental responsibility (PER) & 0.338 & 0.258 & 0.681 & & \\
Social pressure (SP) & 0.667 & 0.516 & 0.415 & 0.326 & \\
Top management support (TMS) & 0.505 & 0.689 & 0.435 & 0.235 & 0.532 & \\
\hline
\end{tabular}

\subsection{Structural model assessment}

Analytical results of the PLS-SEM are implemented step by step according to the guidelines of (Hair, Hult, Ringle, and Sarstedt, 2016). The R-square values of two constructs (openness toward change and top management support) are 0.376 and 0.230 , respectively. Those of proactive behavior and energy saving intention are 0.463 and 0.418 , respectively. Moreover, the f-square indicators are larger than zero. Hence, these testing results satisfy the requirement for the model's predictive power in terms of forecasting outside the sample (Hair et al., 2016; Hair, Ringle, and Sarstedt, 2012). Figure 3 presents the path estimated coefficients in brackets. 


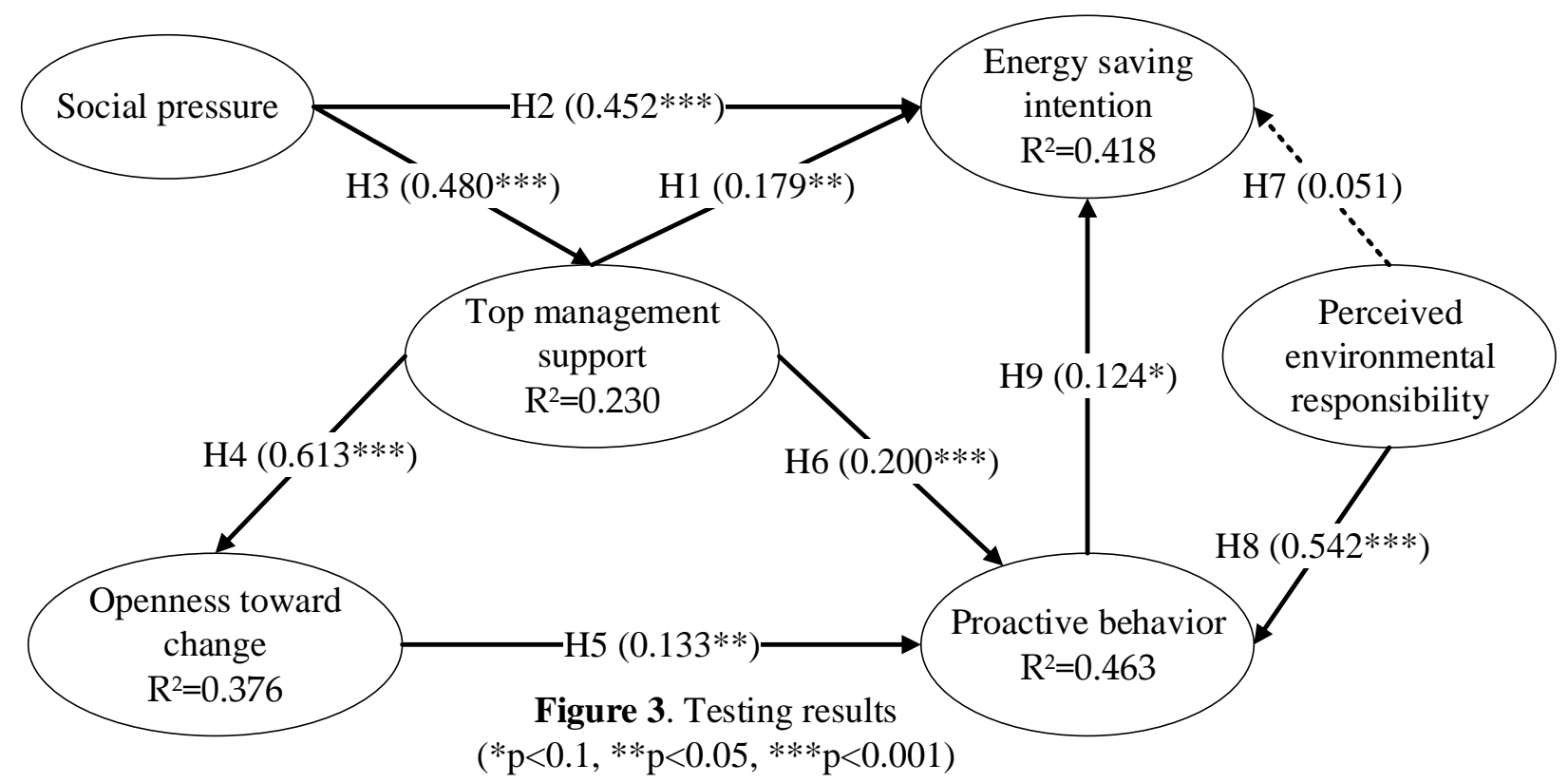

Table 5 reports the path estimated coefficients and respective p-values, and significant level. All the hypotheses are supported with a statistical significance, except for $\mathrm{H} 7$. The testing results indicated that top management support had the strongest influence on openness toward change $(\beta=0.613, p<0.001)$, thus supporting H4. The paths from social pressure to energy saving intention $(\beta=0.452, p<0.001)$, and top management support $(\beta=$ $0.480, \mathrm{p}<0.001$ ) were positive and significant, hence confirming $\mathrm{H} 2$ and $\mathrm{H} 3$. Top management support was positively related to both energy saving intention $(\beta=0.179, \mathrm{p}<0.05)$ and proactive behavior $(\beta=0.200$, $\mathrm{p}<0.001)$, thus supporting $\mathrm{H} 1$ and H6. Openness toward change was positive related to proactive behavior $(\beta=$ $0.133, \mathrm{p}<0.05)$, thus confirming H5. Proactive behavior has a positive impact on energy saving intention $(\beta=$ $0.124, \mathrm{p}<0.1$ ), thus supporting H9. Finally, perceived environmental responsibility was positively related to proactive behavior $(\beta=0.542, p<0.001)$, but not energy saving intention $(\beta=0.051, p=0.340)$, thus confirming $\mathrm{H} 8$, but not $\mathrm{H} 7$.

Table 5. Estimated results

\begin{tabular}{|c|c|c|c|c|c|}
\hline \multicolumn{2}{|c|}{ Hypothesis } & \multirow{2}{*}{$\frac{\text { Beta }}{0.179}$} & \multicolumn{2}{|c|}{ P-value } & Result \\
\hline H1. & $\mathrm{TMS} \rightarrow \mathrm{ESI}$ & & 0.002 & $* *$ & Supported \\
\hline $\mathrm{H} 2$. & $\mathrm{SP} \rightarrow \mathrm{ESI}$ & 0.452 & 0.000 & $* * *$ & Supported \\
\hline H3. & $\mathrm{SP} \rightarrow \mathrm{TMS}$ & 0.480 & 0.000 & $* * *$ & Supported \\
\hline H4. & $\mathrm{TMS} \rightarrow \mathrm{OTC}$ & 0.613 & 0.000 & $* * *$ & Supported \\
\hline H5. & $\mathrm{OTC} \rightarrow \mathrm{PB}$ & 0.133 & 0.033 & $* *$ & Supported \\
\hline H6. & $\mathrm{TMS} \rightarrow \mathrm{PB}$ & 0.200 & 0.001 & $* * *$ & Supported \\
\hline H7. & $\mathrm{PER} \rightarrow \mathrm{ESI}$ & 0.051 & 0.340 & n.s. & Not Supported \\
\hline H8. & $\mathrm{PER} \rightarrow \mathrm{PB}$ & 0.542 & 0.000 & $* * *$ & Supported \\
\hline H9. & TMS->ESB & 0.124 & 0.060 & * & Supported \\
\hline
\end{tabular}

Notes: $* \mathrm{p}<0.05 ; * * \mathrm{p}<0.01 ; * * * \mathrm{p}<0.001 ; \mathrm{n} . \mathrm{s} .=$ non-significance. 


\section{ENTREPRENEURSHIP AND SUSTAINABILITY ISSUES}

ISSN 2345-0282 (online) http://jssidoi.org/jesi/

2020 Volume 8 Number 2 (December)

http://doi.org/10.9770/jesi.2020.8.2(43)

Make your research more visible, join the Twitter account of ENTREPRENEURSHIP AND SUSTAINABILITY ISSUES: @Entrepr69728810

\section{Discussions and implications}

We developed and validated the research model based on the integration of two referenced theories including the social information processing theory, and TPB. The respondents are managers of SMEs in Vietnam. With eight out of the nine suggested hypotheses supported, the findings disclose the following results. The research model, integrated and extended in two theories, can explain an essential circumstance of the reasons why managers intend to save energy at workplaces. First, TPB was extended to explain and predict manager's energy conservation intention and social pressure (extended from subjective norm). The developed hypothesis to capture the impact of social pressure on energy saving intention is supported. This result is in line with prior studies that social pressure, considered as an essential determinant, has a significant influence on energy saving intention of residents (Liu et al., 2020; Wang et al., 2018; Yue et al., 2013); and employees (Scherbaum et al., 2008; Tang et al., 2019). The TPB was also extended by considering perceived environmental responsibility as the predictors of energy-saving intention at workplace. The findings showed that perceived environmental responsibility had no direct effect on energy saving intention; but it had an indirect impact on energy saving intention through proactive behavior. The results were not line with previous studies (Botetzagias et al., 2015; Hua \& Wang, 2019; Lizin et al., 2017; Ru et al., 2018).

Second, the social information processing theory was used to examine the relationship between proactive behavior with both openness toward change and top management support. The findings revealed how managers dealt with the challenges from internal factor such as top management support and exogeneous organizational factor such as openness toward change. However, how managers utilize such substantial factors for saving energy at workplaces remains unknown. The findings showed that manager's proactive behavior was positively associated with energy saving intention. Moreover, top management support had a significantly direct effect and indirect effect on proactive behavior through openness toward change. In turn, openness toward change was positively associated with proactive behavior. This result is in line with the previous finding (Bao et al., 2019). These finding extend our understanding of how managers respond to energy saving intention.

Finally, in the extension of previous behavior literature, we found that top management support played a central role in connecting key factors such as social pressure, openness toward change, proactive behavior, and energy saving intention in the integrated research model. Particularly, the support from top managers not only stimulates middle managers to pursue energy saving actions, but also encourage their ability to transfer positive attitude and openness toward change into proactive behavior. The findings are partially consistent with previous studies on top managers' role in accompanying middle managers' attitude toward environmental responsibility (Bao et al., 2019; Chin, Rowley, Redding, \& Wang, 2018).

\subsection{Theoretical implications}

This paper offers some crucial theoretical implications. First, research on managers' energy saving intention in SMEs retains relatively new and has not been concerned in the prior studies. Previous studies on energy saving phenomenon have concentrated mainly on rational factors (e.g. attitude) of consumers (Gadenne et al., 2011; Hua \& Wang, 2019); residents (Liu et al., 2020; Wang et al., 2018; Yue et al., 2013); employees (Scherbaum et al., 2008; Tang et al., 2019; Zhang et al., 2014). Most of these mentioned studies applied TPB theory to develop the research hypotheses. In addition, in the recent research, Bao et al. (2019) applied the social information processing theory to build the research model to evaluate middle managers' proactive behavior in responding environmental regulation, but not energy saving intention. Ours is among the first studies to integrate and extend both theories of TPB and social information processing to examine managers' responses to energy saving intention at workplaces. 


\section{ENTREPRENEURSHIP AND SUSTAINABILITY ISSUES}

ISSN 2345-0282 (online) http://jssidoi.org/jesi/

2020 Volume 8 Number 2 (December)

http://doi.org/10.9770/jesi.2020.8.2(43)

Make your research more visible, join the Twitter account of ENTREPRENEURSHIP AND SUSTAINABILITY ISSUES: @Entrepr69728810

\subsection{Policy implications}

The results provided some valuable recommendations for practitioners. First, the findings confirm that top management support play a fundamental role in SMEs' saving energy. Accordingly, company leaders should create incentive policies to motivate middle managers to implement energy saving behavior at workplaces. In addition, company leaders should attempt to generate a working environment where everyone is willing to change and has the autonomy to implement proactive behaviors. In other words, managers can share and receive innovative ideas or suggestions to improve the production process with energy efficiency. Second, our results of indirect impact of perceived environmental responsibility on energy saving through proactive behavior also indicate that perceived responsibility stimulates managers to be more proactive in energy-saving actions and evaluates whether their enterprises are ready for pursuing sustainable development. Therefore, company leaders should encourage to widespread propaganda of energy-saving behavior throughout training programs to enhance workers to use energy efficiency. Furthermore, top and middle managers should be more proactive in creating the sustainable business strategy.

\section{Conclusions}

This study shed a new light on managers' energy-saving intention in SMEs. The results enable us to add some theoretical and managerial contributions. We integrated and extended both theories of TPB and the social information processing into developing the research model. The empirical findings confirmed the key role of top management support in stimulating energy saving consumption at workplaces. Under the social pressure, managers are willing to change and stimulate subordinates to reduce energy consumption. They should enhance awareness of environmental responsibility at workplaces to gain the sustainable business development. The more openness toward change, managers are more proactive to seek for innovative ideas and suggestions to use energy efficiency at workplaces. To sum up, this study provides a better understanding of SMEs' energy-saving intention.

\section{Limitations}

Notwithstanding the current study reveals several implications, there are remarkable limitations, which should be investigated in future studies. First, SMEs participated are mainly located in HCMC, Vietnam. Therefore, caution must be taken when generating findings to other regions in Vietnam, other countries and larger corporations due to different cultural and social atmospheres. Second, it is better to extend the research model with external effects such as incentive policies for company investment in new technologies to protect environment. Considering in the external effects, future research can explore different interactions among determinants in the energy saving phenomenon.

\section{References}

Ajzen, I. (1991). The theory of planned behavior. Organizational Behavior and Human Decision Processes, 50(2), $179-211$. https://doi.org/10.1016/0749-5978(91)90020-T

Al-Shemmeri, T., \& Naylor, L. (2017). Energy saving in UK FE colleges: The relative importance of the socio-economic groups and environmental attitudes of employees. Renewable and Sustainable Energy Reviews, 68, 1130-1143. https://doi.org/10.1016/j.rser.2016.08.004

Bao, H., Wang, H., \& Sun, C. (2019). How and when environmental regulation induces middle managers' proactive behavior. Career Development International, 24(5), 438-452. https://doi.org/10.1108/CDI-06-2018-0168 


\section{ENTREPRENEURSHIP AND SUSTAINABILITY ISSUES}

ISSN 2345-0282 (online) http://jssidoi.org/jesi/

2020 Volume 8 Number 2 (December)

http://doi.org/10.9770/jesi.2020.8.2(43)

Make your research more visible, join the Twitter account of ENTREPRENEURSHIP AND SUSTAINABILITY ISSUES: @Entrepr69728810

Becherer, R. C., \& Maurer, J. G. (1999). The proactive personality disposition and entrepreneurial behavior among small company presidents. Journal of Small Business Management, 37(1), 28-36.

Bissing-Olson, M. J., Iyer, A., Fielding, K. S., \& Zacher, H. (2013). Relationships between daily affect and pro-environmental behavior at work: the moderating role of pro-environmental attitude. Journal of Organizational Behavior, 34(2), 156-175.

Blass, V., Corbett, C.J., Delmas, M.A., Muthulingam, S. (2014). Top management and the adoption of energy efficiency practices: evidence from small and medium-sized manufacturing firms in the US. Energy, 65, 560-571. https://doi.org/10.1016/j.energy.2013.11.030

Botetzagias, I., Dima, A. F., \& Malesios, C. (2015). Extending the Theory of Planned Behavior in the context of recycling: The role of moral norms and of demographic predictors. Resources, Conservation and Recycling, 95, 58-67. https://doi.org/10.1016/j.resconrec.2014.12.004

Burke, P. J., \& Csereklyei, Z. (2016). Understanding the energy-GDP elasticity: A sectoral approach. Energy Economics, 58, 199-210. https://doi.org/10.1016/j.eneco.2016.07.004

Chin, T., Rowley, C., Redding, G., \& Wang, S. (2018). Chinese strategic thinking on competitive conflict: insights from Yin-Yang harmony cognition. International Journal of Conflict Management, 29(5), 683-704. https://doi.org/10.1108/IJCMA-09-2017-0101

Chitnis, M., Sorrell, S., Druckman, A., Firth, S. K., \& Jackson, T. (2013). Turning lights into flights: Estimating direct and indirect rebound effects for UK households. Energy Policy, 55, 234-250. https://doi.org/10.1016/j.enpol.2012.12.008

Clark, L. A., \& Watson, D. (1995). Constructing Validity : Basic Issues in Objective Scale Development The Centrality of Psychological Measurement. Psychological Assessment, 7(3), 309-319. https://doi.org/10.1037/1040-3590.7.3.309

Crant, J. M. (1995). The Proactive Personality Scale and Objective Job Performance Among Real Estate Agents. Journal of Applied Psychology, 80(4), 532-537. https://doi.org/10.1037/0021-9010.80.4.532

Crant, J. M. (2000). Proactive behavior in organizations. Journal of Management, 26(3), 435-462. https://doi.org/10.1177/014920630002600304

Cristea, M., Paran, F., \& Delhomme, P. (2013). Extending the theory of planned behavior: The role of behavioral options and additional factors in predicting speed behavior. Transportation Research Part F: Traffic Psychology and Behaviour, 21, 122-132. https://doi.org/10.1016/j.trf.2013.09.009

Dai, J., Montabon, F. L., \& Cantor, D. E. (2014). Linking rival and stakeholder pressure to green supply management: Mediating role of top management support. Transportation Research Part E: Logistics and Transportation Review, 71, $173-187$. https://doi.org/10.1016/j.tre.2014.09.002

Ding, Z., Wang, G., Liu, Z., \& Long, R. (2017). Research on differences in the factors influencing the energy-saving behavior of urban and rural residents in China-A case study of Jiangsu Province. Energy Policy, 100, 252-259. https://doi.org/10.1016/j.enpol.2016.10.013

Escrig-Tena, A. B., Segarra-Ciprés, M., García-Juan, B., \& Beltrán-Martín, I. (2018). The impact of hard and soft quality management and proactive behaviour in determining innovation performance. International Journal of Production Economics, $200,1-14$. https://doi.org/10.1016/j.ijpe.2018.03.011

Fornell, C., \& Larcker, D. F. (1981). Evaluating structural equation models with unobservable variables and measurements error. Journal of Marketing Research, 18(4), 39-50. https://doi.org/10.2307/3151312

Forward, S. E. (2009). The theory of planned behaviour: The role of descriptive norms and past behaviour in the prediction of drivers' intentions to violate. Transportation Research Part F: Traffic Psychology and Behaviour, 12(3), 198-207. https://doi.org/10.1016/j.trf.2008.12.002

Frederiks, E. R., Stenner, K., \& Hobman, E. V. (2015). The socio-demographic and psychological predictors of residential energy consumption: A comprehensive review. Energies, 8(1), 573-609. https://doi.org/10.3390/en8010573

Gadenne, D., Sharma, B., Kerr, D., \& Smith, T. (2011). The influence of consumers' environmental beliefs and attitudes on energy saving behaviours. Energy Policy, 39, 7684-7694. https://doi.org/10.1016/j.enpol.2011.09.002

Gao, L., Wang, S., Li, J., \& Li, H. (2017). Application of the extended theory of planned behavior to understand individual's energy saving 


\section{ENTREPRENEURSHIP AND SUSTAINABILITY ISSUES}

ISSN 2345-0282 (online) http://jssidoi.org/jesi/

2020 Volume 8 Number 2 (December)

http://doi.org/10.9770/jesi.2020.8.2(43)

Make your research more visible, join the Twitter account of ENTREPRENEURSHIP AND SUSTAINABILITY ISSUES: @Entrepr69728810

behavior in workplaces. Resources, Conservation and Recycling, 127, 107-113.

Grant, A. M., \& Ashford, S. J. (2008). The dynamics of proactivity at work. Research in Organizational Behavior, $28,3-34$. https://doi.org/10.1016/j.riob.2008.04.002

Griffin, M. A., Neal, A., \& Parker, S. K. (2007). A new model of work role performance: Positive behavior in uncertain and interdependent contexts. Academy of Management Journal, 50(2), 327-347. https://doi.org/10.5465/AMJ.2007.24634438

Griffin, M. A., Parker, S. K., \& Mason, C. M. (2010). Leader Vision and the Development of Adaptive and Proactive Performance: A Longitudinal Study. Journal of Applied Psychology, 95(1), 174-182. https://doi.org/10.1037/a0017263

Hair, J. F., Ringle, C. M., \& Sarstedt, M. (2012). Partial Least Squares: The Better Approach to Structural Equation Modeling? Long Range Planning, 45(5-6), 312-319. https://doi.org/10.1016/j.lrp.2012.09.011

Hair Jr, J. F., Hult, G. T. M., Ringle, C., \& Sarstedt, M. (2016). A primer on partial least squares structural equation modeling (PLS-SEM). Sage publications.

Hair Jr, J., Sarstedt, M., Hopkins, L., \& G. Kuppelwieser, V. (2014). Partial least squares structural equation modeling (PLS-SEM) An emerging tool in business research. European Business Review, 26(2), 106-121. https://doi.org/10.1108/EBR-10-2013-0128

Hua, L., \& Wang, S. (2019). Antecedents of consumers' intention to purchase energy-efficient appliances: An empirical study based on the technology acceptance model and theory of planned behavior. Sustainability (Switzerland), 11(10), 4-17. https://doi.org/10.3390/su11102994

Jacobson, R. (1992). The "Austrian” School of Strategy. Academy of Management Review, 17(4), 782-807. https://doi.org/10.5465/amr.1992.4279070

Jahanshahi, A. A., \& Brem, A. (2017). Sustainability in SMEs: Top management teams behavioral integration as source of innovativeness. Sustainability (Switzerland), 9(10), 1-16. https://doi.org/10.3390/su9101899

Kaiser, F. G., \& Gutscher, H. (2003). The proposition of a general version of the theory of planned behavior: Predicting ecological behavior. Journal of Applied Social Psychology, 33(3), 586-603. https://doi.org/10.1111/j.1559-1816.2003.tb01914.x

Kickul, J., \& Gundry, L. (2002). Prospecting for Strategic Advantage: The Proactive Entrepreneurial Personality and Small Firm Innovation. Journal of Small Business Management, 40(2), 85-97. https://doi.org/10.1111/1540-627x.00042

Le, P. V. (2019). Energy demand and factor substitution in Vietnam: evidence from two recent enterprise surveys. Journal of Economic Structures, 8(1), 1-17. https://doi.org/10.1186/s40008-019-0168-9

Lee, K. (2009). Gender differences in Hong Kong adolescent consumers' green purchasing behavior. Journal of Consumer Marketing, 26(2), 87-96.

Leygue, C., Ferguson, E., \& Spence, A. (2017). Saving energy in the workplace: Why, and for whom? Journal of Environmental Psychology, 53, 50-62. https://doi.org/10.1016/j.jenvp.2017.06.006

Li, D., Xu, X., Chen, C. fei, \& Menassa, C. (2019). Understanding energy-saving behaviors in the American workplace: A unified theory of motivation, opportunity, and ability. Energy Research and Social Science, 51, 198-209. https://doi.org/10.1016/j.erss.2019.01.020

Liu, X., Wang, Q., Wei, H. H., Chi, H. L., Ma, Y., \& Jian, I. Y. (2020). Psychological and demographic factors affecting household energysaving intentions: A TPB-based study in northwest China. Sustainability (Switzerland), 12(3), 1-20. https://doi.org/10.3390/su12030836

Lizin, S., Van Dael, M., \& Van Passel, S. (2017). Battery pack recycling: Behaviour change interventions derived from an integrative theory of planned behaviour study. Resources, Conservation and Recycling, 122, 66-82. https://doi.org/10.1016/j.resconrec.2017.02.003

Maden, C. (2015). Linking high involvement human resource practices to employee proactivity: The role of work engagement and learning goal orientation. Personnel Review, 44(5), 720-738. https://doi.org/10.1108/PR-01-2014-0030

Miller, Vernon D., Johnson, John R., Grau, J. (1994). Antecedents to Willingness to Participate in a Planned Organizational Chang...: EBSCOhost. Journal of Applied Communication Research, 22(1), 59-80. 


\section{ENTREPRENEURSHIP AND SUSTAINABILITY ISSUES}

ISSN 2345-0282 (online) http://jssidoi.org/jesi/

2020 Volume 8 Number 2 (December)

http://doi.org/10.9770/jesi.2020.8.2(43)

Make your research more visible, join the Twitter account of ENTREPRENEURSHIP AND SUSTAINABILITY ISSUES: @Entrepr69728810

Nyangarika, A., Mikhaylov, A., \& Richter, U. H. (2019). Oil price factors: Forecasting on the base of modified auto-regressive integrated moving average model. International Journal of Energy Economics and Policy, 9(1), 149-159. https://doi.org/10.32479/ijeep.6812

Park, E., \& Kwon, S. J. (2017). What motivations drive sustainable energy-saving behavior?: An examination in South Korea. Renewable and Sustainable Energy Reviews, 79, 494-502.

Parker, S. K., Williams, H. M., \& Turner, N. (2006). Modeling the antecedents of proactive behavior at work. Journal of Applied Psychology, 91(3), 636-652. https://doi.org/10.1037/0021-9010.91.3.636

Rai, V., \& Beck, A. L. (2015). Public perceptions and information gaps in solar energy in Texas. Environmental Research Letters, 10(7), 1-9. https://doi.org/10.1088/1748-9326/10/7/074011

Rice, G. (2006). Pro-environmental behavior in Egypt: Is there a role for Islamic environmental ethics? Journal of Business Ethics, 65(4), 373-390. https://doi.org/10.1007/s10551-006-0010-9

Ru, X., Wang, S., \& Yan, S. (2018). Exploring the effects of normative factors and perceived behavioral control on individual's energysaving intention: An empirical study in eastern China. Resources, Conservation and Recycling, 134, 91-99. https://doi.org/10.1016/j.resconrec.2018.03.001

Scherbaum, C. A., Popovich, P. M., \& Finlinson, S. (2008). Exploring individual-level factors related to employee energy-conservation behaviors at work. Journal of Applied Social Psychology, 38(3), 818-835. https://doi.org/10.1111/j.1559-1816.2007.00328.x

Seibert, S. E., Kraimer, M. L., \& Crant, J. M. (2001). What do proactive people do? A longitudinal model linking proactive personality and career success. Personnel Psychology, 54(4), 845-874. https://doi.org/10.1111/j.1744-6570.2001.tb00234.x

Tan, C. S., Ooi, H. Y., \& Goh, Y. N. (2017). A moral extension of the theory of planned behavior to predict consumers' purchase intention for energy-efficient household appliances in Malaysia. Energy Policy, 107, 459-471. https://doi.org/10.1016/j.enpol.2017.05.027

Tang, Z., Warkentin, M., \& Wu, L. (2019). Understanding employees' energy saving behavior from the perspective of stimulus-organismresponses. Resources, Conservation and Recycling, 140, 216-223. https://doi.org/10.1016/j.resconrec.2018.09.030

Tran, K. T., \& Nguyen, P. V. (2020). Corporate social responsibility: Findings from the vietnamese paint industry. Sustainability (Switzerland), 12(3), 1-20. https://doi.org/10.3390/su12031044

Wang, L., Wei, F., \& Zhang, X. (2019). Why Does Energy-Saving Behavior Rise and Fall? A Study on Consumer Face Consciousness in the Chinese Context. Journal of Business Ethics, 160(2), 499-513. https://doi.org/10.1007/s10551-018-3944-9

Wang, S., Lin, S., \& Li, J. (2018). Exploring the effects of non-cognitive and emotional factors on household electricity saving behavior. Energy Policy, 115, 171-180. https://doi.org/10.1016/j.enpol.2018.01.012

Wang, Z., Zhang, B., \& Li, G. (2014). Determinants of energy-saving behavioral intention among residents in Beijing: Extending the theory of planned behavior. Journal of Renewable and Sustainable Energy, 6(5), 053127. https://doi.org/10.1063/1.4898363

World Bank. (2019). Energy intensity level of primary energy. Retrieved from https://databank.worldbank.org/reports.aspx?source=2\&series=EG.EGY.PRIM.PP.KD

Yang, S., Zhang, Y., \& Zhao, D. (2016). Who exhibits more energy-saving behavior in direct and indirect ways in china? The role of psychological factors and socio-demographics. Energy Policy, 93, 196-205. https://doi.org/10.1016/j.enpol.2016.02.018

Yue, T., Long, R., \& Chen, H. (2013). Factors influencing energy-saving behavior of urban households in jiangsu province. Energy Policy, 62, 665-675. https://doi.org/10.1016/j.enpol.2013.07.051

Zhang, B., Wang, Z., \& Lai, K. hung. (2015). Mediating effect of managers' environmental concern: Bridge between external pressures and firms' practices of energy conservation in China. Journal of Environmental Psychology, 43, 203-215. https://doi.org/10.1016/j.jenvp.2015.07.002

Zhang, Y., Wang, Z., \& Zhou, G. (2014). Determinants of employee electricity saving: The role of social benefits, personal benefits and organizational electricity saving climate. Journal of Cleaner Production, 66, 280-287. https://doi.org/10.1016/j.jclepro.2013.10.021

Zhang, Y., Wei, Y., \& Zhou, G. (2018). Promoting firms' energy-saving behavior: The role of institutional pressures, top management support and financial slack. Energy Policy, 115(January), 230-238. 
ENTREPRENEURSHIP AND SUSTAINABILITY ISSUES

ISSN 2345-0282 (online) http://jssidoi.org/jesi/

2020 Volume 8 Number 2 (December)

http://doi.org/10.9770/jesi.2020.8.2(43)

Make your research more visible, join the Twitter account of ENTREPRENEURSHIP AND SUSTAINABILITY ISSUES: @Entrepr69728810

\section{Appendix A.}

Table A1. Measure scale

\begin{tabular}{|c|c|c|c|c|}
\hline \multicolumn{2}{|c|}{ Variables } & Code & Items & $\begin{array}{l}\text { Adapted and } \\
\text { modified from } \\
\text { previous studies }\end{array}$ \\
\hline \multirow{4}{*}{\multicolumn{2}{|c|}{ Social pressure }} & SP1 & $\begin{array}{l}\text { Most people who are important to me think I should save } \\
\text { energy. }\end{array}$ & \multirow{4}{*}{$\begin{array}{l}\text { (Tang et al., 2019; } \\
\text { Zhang et al., 2014) }\end{array}$} \\
\hline & & SP2 & My director expects me to save energy. & \\
\hline & & SP3 & My colleagues expect me to save energy. & \\
\hline & & SP4 & $\begin{array}{l}\text { I feel pressured due to the energy-saving activities of my } \\
\text { colleagues }\end{array}$ & \\
\hline \multirow{9}{*}{ Proactive behavior } & \multirow{3}{*}{$\begin{array}{l}\text { Individual task } \\
\text { proactivity }\end{array}$} & PB1 & Initiated better ways of doing my core tasks & \multirow{9}{*}{$\begin{array}{l}\text { (Bao et al., 2019; } \\
\text { Griffin et al., 2007) }\end{array}$} \\
\hline & & PB2 & $\begin{array}{l}\text { Come up with ideas to improve the way in which my core } \\
\text { tasks are done }\end{array}$ & \\
\hline & & PB3 & Made changes to the way your core tasks are done & \\
\hline & \multirow{3}{*}{$\begin{array}{l}\text { Team member } \\
\text { proactivity }\end{array}$} & PB4 & Suggested ways to make my work unit more effective & \\
\hline & & PB5 & $\begin{array}{l}\text { Developed new and improved methods to help my work unit } \\
\text { perform better }\end{array}$ & \\
\hline & & PB6 & Improved the way my work unit does things & \\
\hline & \multirow{3}{*}{$\begin{array}{l}\text { Organization } \\
\text { member } \\
\text { proactivity }\end{array}$} & PB7 & $\begin{array}{l}\text { Made suggestions to improve the overall effectiveness of the } \\
\text { organization (e.g., by suggesting changes to administrative } \\
\text { procedures) }\end{array}$ & \\
\hline & & PB8 & $\begin{array}{l}\text { Involved myself in changes that are helping to improve the } \\
\text { overall effectiveness of the organization }\end{array}$ & \\
\hline & & PB9 & $\begin{array}{l}\text { Come up with ways of increasing efficiency within the } \\
\text { organization }\end{array}$ & \\
\hline \multirow{4}{*}{\multicolumn{2}{|c|}{ Top management support }} & TMS1 & $\begin{array}{l}\text { Top management team in my organization is committing to } \\
\text { implement environmental protection }\end{array}$ & \multirow{4}{*}{$\begin{array}{l}\text { (S. Wang et al., } \\
\text { 2018) }\end{array}$} \\
\hline & & TMS2 & $\begin{array}{l}\text { The implementation of environmental protection can receive } \\
\text { full support from my top management team }\end{array}$ & \\
\hline & & TMS3 & $\begin{array}{l}\text { Top management team can provide adequate resources to } \\
\text { support the implementation of environmental protection }\end{array}$ & \\
\hline & & TMS4 & $\begin{array}{l}\text { Top management team consistently assesses the business } \\
\text { impact on the environment by implementing environmental } \\
\text { protection }\end{array}$ & \\
\hline \multirow{5}{*}{\multicolumn{2}{|c|}{$\begin{array}{l}\text { Perceived environmental } \\
\text { responsibility }\end{array}$}} & PER1 & $\begin{array}{l}\text { It is essential to promote environmental responsibility at } \\
\text { workplaces }\end{array}$ & \multirow{5}{*}{$\begin{array}{c}\text { (Lee, 2009; L. } \\
\text { Wang et al., 2019) }\end{array}$} \\
\hline & & PER2 & $\begin{array}{l}\text { I strongly agree that more environmental protection works are } \\
\text { needed }\end{array}$ & \\
\hline & & PER3 & I concern for environmental protection issues & \\
\hline & & PER4 & I think environmental protection is meaningful & \\
\hline & & PER5 & $\begin{array}{l}\text { It is very important to raise environmental awareness at } \\
\text { workplaces }\end{array}$ & \\
\hline \multirow{2}{*}{\multicolumn{2}{|c|}{ Openness toward change }} & OTC1 & $\begin{array}{l}\text { I would consider myself to be "open" to the changes the work } \\
\text { teams will bring to my work role }\end{array}$ & \multirow{2}{*}{$\begin{array}{l}\text { (Bao et al., 2019; } \\
\text { Miller et al., 1994) }\end{array}$} \\
\hline & & OTC2 & $\begin{array}{l}\text { Right now, I am somewhat easy to the proposed changes in } \\
\text { work teams }\end{array}$ & \\
\hline
\end{tabular}


ENTREPRENEURSHIP AND SUSTAINABILITY ISSUES

ISSN 2345-0282 (online) http://jssidoi.org/jesi/

2020 Volume 8 Number 2 (December)

http://doi.org/10.9770/jesi.2020.8.2(43)

Make your research more visible, join the Twitter account of ENTREPRENEURSHIP AND SUSTAINABILITY ISSUES: @Entrepr69728810

\begin{tabular}{|c|c|c|c|}
\hline & OTC3 & $\begin{array}{l}\text { I am looking forward to the changes in my work role brought } \\
\text { about by the implementation of work teams }\end{array}$ & \\
\hline & OTC4 & $\begin{array}{l}\text { I think that the implementation of work teams will have a } \\
\text { positive effect on how I accomplish } \\
\text { my work. }\end{array}$ & \\
\hline & OTC5 & $\begin{array}{l}\text { From my perspective, the proposed changes in the work } \\
\text { teams will be for the better. }\end{array}$ & \\
\hline \multirow{4}{*}{ Energy saving intention } & ESI1 & I am willing to save energy for my organization & \multirow{4}{*}{$\begin{array}{l}\text { (Gao et al., 2017; } \\
\text { Park and Kwon, } \\
\text { 2017; Tang et al., } \\
\text { 2019) }\end{array}$} \\
\hline & ESI2 & $\begin{array}{l}\text { I intend to engage in energy-saving activities in my } \\
\text { organization }\end{array}$ & \\
\hline & ESI3 & I will make an effort to save energy in my organization & \\
\hline & ESI4 & I recommend others use energy-saving in my organization & \\
\hline
\end{tabular}

Source: Data collection

Phuong V. NGUYEN is currently an Associate Professor of Business Management at International University, Vietnam National University, Ho Chi Minh City. Before becoming a Lecturer, he had 11 years of working experience in Telecom Industry in Vietnam. He has participated in several consulting projects as the role of a financial manager, project leader, and strategic business advisor. Since working in the academic field, his research interests include the technology spillovers, international strategies, and innovation from foreign direction investment and behavioural studies on business management and public administration.

ORCID ID: orcid.org/0000-0002-2034-4471

Khoa T. TRAN is the Rector of International University, Vietnam National University, Ho Chi Minh City. He received his MBA in International Business at Asia Institution of Technology in Thailand in 1996. He completed his doctorate degree in Marketing and International Business at Western Sydney University, Australia in 2014. His research interests include educational management, brand development, international marketing, technology transfers and behavioural studies on business management and public management.

ORCID ID: orcid.org/0000-0002-4498-5871

Copyright (C) 2020 by author(s) and VsI Entrepreneurship and Sustainability Center

This work is licensed under the Creative Commons Attribution International License (CC BY).

http://creativecommons.org/licenses/by/4.0/

(c) (i) Open Access 